\title{
Micro-credit for the Small Enterprises Development: A Case of Kaski District, Nepal
}

\author{
${ }^{1}$ Deepesh Ranabhat \\ ${ }^{2}$ Bharat Ram Dhungana, PhD \\ ${ }^{1,2}$ School of Business, Pokhara University, Nepal
}

Article History: Submitted 31 January 2021; Reviewed 18 April 2021; Accepted 20 April 2021 Corresponding Author: Bharat Ram Dhungana, Email: dhunganabharat.pu@gmail.com DOI: https://doi.org/10.3126/paj.v4i0.37007

Copyright 2021 (c) Author/s and Centre for Research and Innovation. This work is licensed under a Creative Commons Attribution 4.0 International (CC BY 4.0) License.
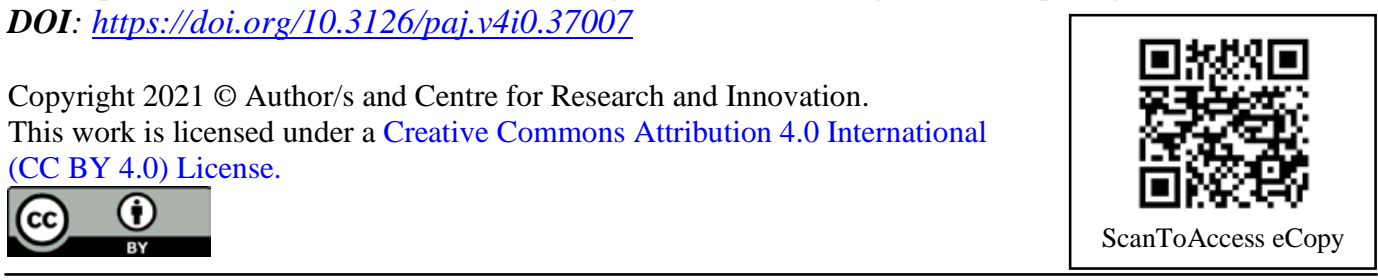

\begin{abstract}
The aim of this paper is to examine the impact of micro-credit on the small or microenterprises development with reference to Kaski district of Nepal. The descriptive and analytical research design is used and the research is based on the primary sources of data collected through structured questionnaires. During the study, the researchers selected 170 respondents, who were involved in the micro-credit programme in the last five or more years in the microfinance institutions, using the purposive sampling technique. The study finds that the majority of the clients are involved in agriculture and livestock and the rest are involved in the micro-business and enterprises related to service industry (such as tailoring, beauty parlor, hotel or restaurant), trade or business and small-scale manufacturing sectors. Micro-credit has a positive correlation with initial investment, revenue generation, employment generation, expansion of business and profit generation. The study also finds that micro-credit has encouraged clients to engage in the micro-business and enterprise development activities. The study recommends that it is necessary to adopt an effective utilization policy of micro-credit that may benefit both microfinance institutions for its sustainability and clients for their living standard improvement.
\end{abstract}

KEYWORDS: Micro-credit, micro-business, micro-enterprises, microfinance institutions

\section{INTRODUCTION}

The micro-enterprise development is an important strategy for employment generation and poverty alleviation in developing countries like Nepal. Microfinance is considered as an important approach to transform the socio-economic status of the poor and unbanked people through micro-credit services and its productive application in micro or small businesses. Schumpeter (1934) concluded that the financial sector is an engine of economic growth through its funding of productive investment. A well- 
developed financial institution promotes the level of capital formation and encourages investment by identifying and financing productive business opportunities. The development of financial sector has a significant impact on the economic growth of the nation through mobilization of accumulated capital into the productive sectors.

Insufficient finance is a key obstacle to firm growth (Malhotra et al., 2007) and it has been found that small firms face bigger challenges in obtaining finance as compared to larger firms (Schiffer \& Weder, 2001; Beck et al., 2008). Financing is important for firms because it helps in expansion of operations, innovation, and investing in production facilities and new staff (OECD, 2006). There has been increased attention focused on the role of firms in affecting economic growth, employment creation, and poverty reduction. Firms have been identified as important avenues for employment and job creation in both developing and developed countries.

Microfinance (MF) is a tool of financial inclusion and poverty reduction. It provides financial services to the people who have no access to formal financial institutions such as commercial banks. Microfinance institutions (MFIs) provide a wide range of financial services generally micro-savings, micro-credit, micro-insurance and payment services. The aim of MFIs is to render financial and non-financial services to the people that ultimately help to transform their socio-economic status. The aim of MFIs includes (i) reducing poverty, (ii) empowering women or other disadvantaged population groups, (iii) creating employment, and (iv) encouraging for micro-business enterprises creation. Dhungana (2018) finds micro-business and enterprises creation of people have been significantly improved after involvement in micro-finance programs.

Microfinance plays an important role in fighting the multi-dimensional aspects of poverty. It is an innovation for the developing countries like Nepal. It provides a selfemployment opportunity for the poor people who are unemployed, entrepreneurs and farmers who are not bankable because of the lack of collateral, very low level of income. It has successfully enabled the poor people to start their own business generating income and often beginning to build up wealth. It has the capacity to enhance the socioeconomic development of the vulnerable and marginalized people, especially women.

The financial inclusion is a burning agenda in developing countries like Nepal where a large number of people are still far from access to formal banking services. The marginalized and vulnerable people, who have been exploited by the informal lending system and no capacity to pledge physical collateral for the loan, are the major target of financial inclusion. The status of financial inclusion in the case of Nepal is not satisfactory and still more than half of the adult people are unbanked. The account penetration at formal financial institutions in 2011 was 25.3 percent and increased to 45.4 percent in 2017. The financial inclusion in Nepal is below the average of South Asia i.e., 69.6 percent (The World Bank, 2017).

The most desired target of any development strategy in developing countries is to enhance the economic growth and reduce poverty. The creation of employment opportunities through the development of micro-enterprises, small and medium enterprises (SMEs), and large enterprises is considered as an effective process (Green et al., 2006). Micro-credit plays an important role in creation of employment through the development of enterprise. The objective of this paper is to examine the impact of microcredit on the micro-enterprises development with reference to Kaski district of Nepal. The specific objectives are: (i) to assess the impact of micro-credit on employment generation, revenue generation, return on investment, and enterprises expansion. (ii) to examine the relationship between demographic variables and micro-enterprises development. 


\section{LITERATURE REVIEW}

The efficiency of micro-credits for small businesses can be assessed by various criteria such as the growth rate of firms, their productivity, profitability, income and net assets, poverty reduction, and women's empowerment (Yang, 2018; Akhter \& Cheng, 2020). The micro-entrepreneurs need financing for their survival but they do not care whether the financing comes from family, friends or a particular financial institution (Mor et al., 2020). Microfinance has transformed economic status of the people through the productive application of micro-credit (Dhungana, 2018).

Kapoor and Dhaka (2017) analysed the impact of micro-credit on profitability, physical assets and capital structure. The study finds positive relationship with microcredit and the sales revenue, physical assets and capital structure. Likewise, micro-credit has a positive impact on the development and growth of the SMEs.

Dhungana (2016) examines the loan size and its productive application after involvement in the microfinance programme in the western development region of Nepal. The study shows that there is a positive association between the size of savings and loans, size of savings and loan application, current loan size and ethnicity, loan size and duration of membership, and finally loan size and its application. It has been found that clients who have taken a small size of loans, they have mostly spent their loans on domestic purposes and found a poor application of loans in the micro-business whereas a big loan size clients have a greater application of loans in productive sectors.

The micro-business or enterprises creation, income level, consumption expenditure and capital expenditure of clients have been significantly improved after involvement in microfinance programme (Dhungana, 2016). The microfinance institutions create self-employment opportunities, improving labor productivity and increasing wage rates through micro-credit (Wanjiku \& Njiru, 2016). Microfinance provides finance to women who helped them to start or expand the business (Khanday et al., 2015). Women's involvement in business raises women's independent incomes and savings, increases their family monthly income and other household resources which are the basis for women's economic empowerment (Rehman et al., 2015).

Dhungana (2015) finds that due to the micro-business or enterprises creation, employment generation, occupational status, and income level of the people have been significantly improved, as it involved in the microfinance programme in Nepal. Microfinance has facilitated to generate self-employment and employment opportunities through micro-credit services; however, there is lacking of enough orientation regarding the productive application of loans.

Salia and Mbwambo (2014) examine the effect of micro-credit on borrowers businesses of women owned micro-enterprises in Tanzania. The study shows that businesses of borrowers are performing significantly better than those of non-borrowers on total sales revenue and business net worth. Moreover, the study concludes that microcredit is a useful tool to alleviate poverty among women through income generation activities resulting from their involvement in micro-enterprise activities.

Khalily and Khaleque (2013) find a relationship between an access to credit and the factor productivity of enterprises. The results show that the access to credit (i) contributes to high average labor productivity and (ii) influences total factor productivity positively. The robustness of the findings is tested by the effect of quantity rationing on the outcomes using the endogenous switching regression models as the alternate of the used models.

Teng et al. (2011) assess impacts of micro-credit on the household economics of Cambodia. The study reveals that the clients who are involved in the micro-credit programme have found better living standards due to its growth in income and assets. In 
addition, micro-credit has created more job opportunities and improved household education, women's status, family welfare, and variety of economic activities. It has reduced income inequality and poverty through a productive use of the micro-credit.

There is a positive impact of micro-credit on socio-economic indicators, such as employment creation (Arinaitwe, 2006; Khandker et al., 1998), income and expenditure of the target groups (Hietalahti \& Linden, 2006), savings (Copestake et al., 2001), asset ownership (Bhatt et al., 1999), wealth and comfort of family and community (Ang, 2004), and the standard of living of the participants. A number of evidences show that micro-credit increased the profit rate of small enterprises (Hietalahti \& Linden, 2006; Copestake et al., 2001).

Figure 1 depicts the conceptual framework of access to micro-credit and of micro-enterprises.

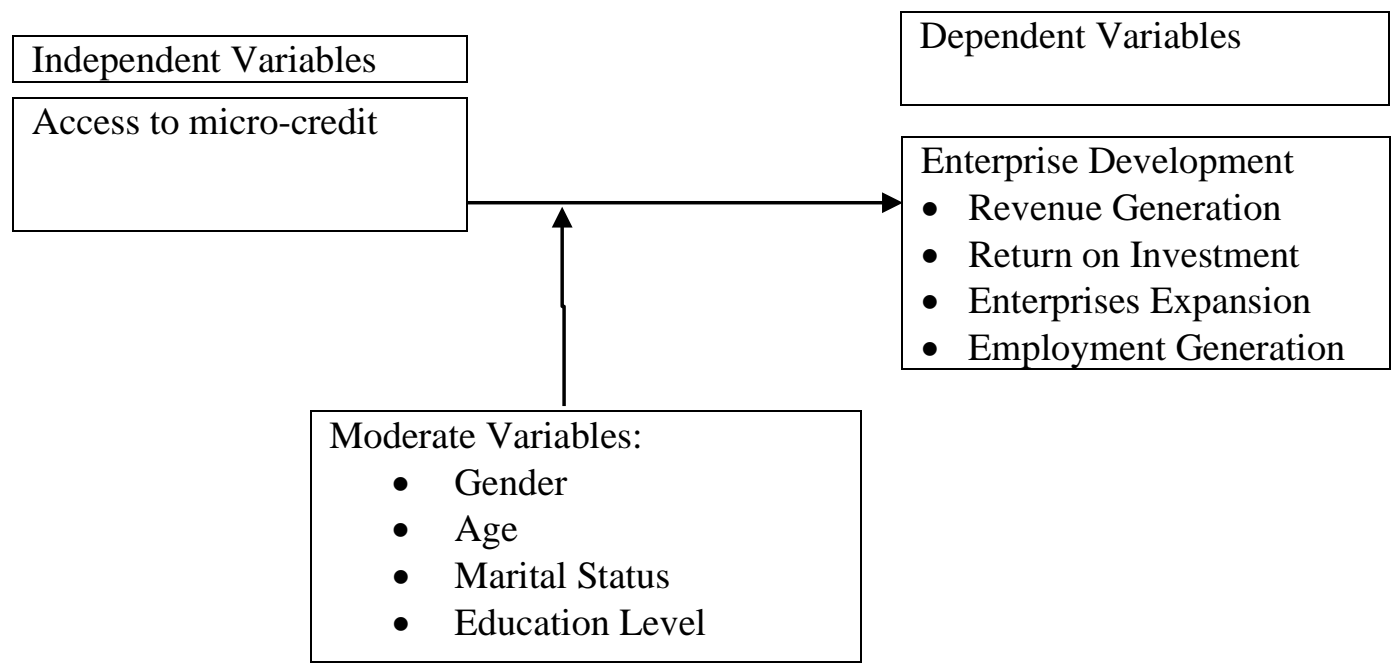

Fig. 1: The Conceptual Framework

On the basis of above conceptual framework following hypotheses have been developed in this study:

$\boldsymbol{H}_{1}$ : The access to micro-credit increases revenue to the micro-enterprises.

$\boldsymbol{H}_{2}$ : The access to micro-credit enhances return on investment to the micro-enterprises.

$\boldsymbol{H}_{3}$ : The access to micro-credit expands micro-enterprises or business.

$\boldsymbol{H}_{\mathbf{4}}$ : The access to micro-credit generates employment opportunities.

$\boldsymbol{H}_{\mathbf{5}}$ : There is association between demographic variables and micro-enterprises development.

\section{DATA AND METHODS}

This study follows descriptive and analytical research designs to explain the characteristics of respondents, micro credit and micro enterprises, and the association between the variables. The study is based on the primary sources of data. The primary data has been collected through structured questionnaires. The structured questionnaires have been developed and administered to the MF clients who have been involved in the micro-credit programme of MFIs in the last five or more years. To identify the years of involvement in MFIs, the passbook of respondents provided by the microfinance institutions has been verified. The study area has been confined to Kaski district of Nepal. The researchers have selected 170 respondents as the sample size at $7.5 \%$ margin of error and 95\% confidence interval using the Raosoft sample size calculator. For 
sampling, at first stage five MFIs namely Muktinath, Nirdhan Utthan, NMB, Nesdo, and Dhaulagiri Laghubitta Bittiya Sanstha have been selected and then 34 respondents from each MFIs who have been involved in the micro-credit programme in the last five years or more have been selected for data collection using the purposive sampling technique. The collected data have been analysed with the help of statistical tools such as frequency analysis, chi-square test, correlation analysis using SPSS and MS-Excel. This study has a limitation of confining the study within the Kaski district having 170 sample size of respondents.

\section{RESULTS AND DISCUSSION}

\section{Demographic Profile of Respondents}

The demographic characteristics for the respondents have been presented in Table 1 in terms of gender, age, level of education, ethnicity, marital status, and occupation status.

Table 1

Demographic Profile of Respondents

\begin{tabular}{|c|c|c|c|c|c|}
\hline $\begin{array}{l}\text { Demograph } \\
\text { ic Variable }\end{array}$ & Freq. & Percent & $\begin{array}{c}\text { Demographic } \\
\text { Variable }\end{array}$ & Freq. & Percent \\
\hline \multicolumn{3}{|c|}{ Household Head } & \multicolumn{3}{|c|}{ Ethic Group } \\
\hline Male & 82 & 48.2 & Dalit & 40 & 23.5 \\
\hline Female & 88 & 51.8 & Janajati \& Adhibasi & 61 & 35.9 \\
\hline \multicolumn{3}{|c|}{ Age structure } & Others & 69 & 40.6 \\
\hline 20 to 30 & 12 & 7.1 & \multicolumn{3}{|c|}{ Education } \\
\hline 31 to 40 & 65 & 38.2 & Illiterate & 12 & 7.1 \\
\hline 41 to 50 & 77 & 45.3 & Primary Education & 69 & 40.6 \\
\hline 50 Above & 16 & 9.4 & $\begin{array}{l}\text { Secondary } \\
\text { Education }\end{array}$ & 61 & 35.9 \\
\hline \multicolumn{3}{|c|}{ Marital Status } & Above Secondary & 28 & 16.5 \\
\hline Married & 152 & 89.4 & \multicolumn{3}{|c|}{ Occupation Status } \\
\hline Unmarried & 4 & 2.4 & Jobs & 27 & 15.9 \\
\hline $\begin{array}{l}\text { Divorced/Se } \\
\text { parated }\end{array}$ & 6 & 3.5 & Business & 44 & 25.9 \\
\hline Widow & 8 & 4.7 & $\begin{array}{l}\text { Agriculture and } \\
\text { Livestock }\end{array}$ & 99 & 58.2 \\
\hline Total & 170 & 100.0 & Total & 170 & 100.0 \\
\hline
\end{tabular}

Source: Field Survey, 2020.

The majority of the respondents' household head are female. Most of the respondents are within the age category of 31- 50 years (83.5\%) and married (89.4\%). Likewise, majority of the respondents (52.4\%) have the secondary and above level education. The respondents having the primary education (40.6 percent) reflect their involvement in MFIs to initiate the micro-enterprise development is meaningful. The involvement of disadvantaged people such as Dalit (23.5\%) are the major target for the socio-economic transformation. Others include upper caste such as Brahamin and Chettri (40.6\%). Majority of the respondents (58.2\%) are involved in agriculture and livestock and remaining are in the business (25.9\%) and jobs (15.9\%) respectively. 


\section{Micro-credit Status of the Clients}

The micro-credit status of the clients refers to the size of the micro-credit taken by MF clients. Table 2 denotes the micro-credit status of the clients.

Table 2

Micro-credit Status of the Client

\begin{tabular}{lcc}
\hline $\begin{array}{c}\text { Size of Micro-credit } \\
\text { (NRs) }\end{array}$ & Frequency & Percentage \\
\hline Below 100,000 & 16 & 9.4 \\
100,001 to 300,000 & 115 & 67.6 \\
300,001 to 500,000 & 33 & 19.4 \\
More than 500,000 & 6 & 3.5 \\
Total & $\mathbf{1 7 0}$ & $\mathbf{1 0 0}$ \\
\hline
\end{tabular}

Source: Field survey, 2020.

Note: NRs represent Nepalese rupees. 1 USD is equivalent to 117.55 NRs as per the foreign exchange rate determined by Central Bank of Nepal on January 19, 2021.

Most of the clients (87\%) have taken the micro-credit between NRs 100,001 to 500,000 . Only $9.4 \%$ clients have taken the micro-credit below NRs 100,000 and 3.5\% clients have taken the micro-credit above NRs 500,000. Dhungana (2016) finds big loan size clients have a greater application of loans in the productive sectors. Since the size of the micro-credit matters for the productive application, most of the clients may be interested to initiate or expand micro-enterprises with the help of micro-credit.

\section{Nature of Micro-business}

The nature of micro-business initiated and operated by the MF clients with the help of micro-credit has been presented in Table 3 .

Table 3

Nature of Micro-business

\begin{tabular}{lll}
\hline Nature of Micro-business & Frequency & Percent \\
\hline Manufacturing & 15 & 8.8 \\
Trade or business & 31 & 18.2 \\
Services & 42 & 24.7 \\
Agriculture and livestock & 82 & 48.3 \\
Total & $\mathbf{1 7 0}$ & $\mathbf{1 0 0}$ \\
\hline
\end{tabular}

Source: Field survey, 2020.

Majority of micro-business or enterprises are related to agriculture and livestock (48.3\%). The rest of are related to service industry such as tailoring, beauty parlor, hotel or restaurant $(24.7 \%)$, trade or business $(18.2 \%)$, and small-scale manufacturing or production (8.8\%) area respectively.

\section{Level of Investment} in Table 4.

The level of investment in tiny businesses by the MF clients has been presented 
Table 4

Level of Investment

\begin{tabular}{lll}
\hline Total Investment (NRs) & Frequency & Percent \\
\hline Below 100,000 & 16 & 9.4 \\
100,001 to 300,000 & 113 & 66.5 \\
300,001 to 500,000 & 23 & 13.5 \\
Above 500,000 & 18 & 10.6 \\
Total & $\mathbf{1 7 0}$ & $\mathbf{1 0 0}$ \\
\hline
\end{tabular}

Source: Field survey, 2020.

Majority of clients (66.5\%) have invested NRs 100,0000 to 300,0000 in microenterprises or tiny businesses. It is followed by 13.5 percent respondents who have invested three lakhs to five lakhs in micro-enterprises. Similarly, 10.6 percent respondents have invested above five lakhs in micro-enterprises and 9.4 percent respondents have invested below one lakh in micro-enterprises.

\section{Reasons for Taking Micro-credit}

The key reasons for taking the micro-credit by the MF clients have been presented in Table 5.

Table 5

Reasons for Taking Micro-credit

\begin{tabular}{llllll}
\hline $\begin{array}{l}\text { Enterprise } \\
\text { Development }\end{array}$ & Frequency & Percent & Major Reasons & Frequency & Percent \\
\hline Yes & 160 & 94 & No Need of Collateral & 60 & 37.50 \\
No & 10 & 6 & Easy Payment System & 81 & 50.63 \\
& & & Easy and Quick Loan & 19 & 11.88 \\
& & & Total & $\mathbf{1 6 0}$ & $\mathbf{1 0 0 . 0 0}$
\end{tabular}

Source: Field survey, 2020.

It is obvious from the above table that most of the respondents (94\%) are agreed; micro-credit helps for enterprise development. Majority of the respondents (50.63\%) have opined that reasons for taking micro-credit is easy payment system. The other key reasons for taking micro-credit are no need of collateral (37.5 \%) and the easy and quick loan $(11.88 \%)$.

\section{Association between Demographic Variables and Initial investment}

This includes the association between demographic variables like gender, age structure, ethnic group, marital status, and level of education with the micro-enterprises related variables such as an initial investment. The chi-square test has been used to show the association between these variables. The result of chi-square test has been presented in Table 6.

Table 6

Association between Demographic Variables and Initial Investment

\begin{tabular}{llc}
\hline Demographic Variables & $\chi^{2}$ & Significant \\
\hline Gender - Household Head & 18.015 & 0.001 \\
Age Structure & 14.539 & 0.268 \\
\hline Prithvi Academic Journal, Volume 4, May 2021 [pp. 27-38] & 33 | P a g e
\end{tabular}




\begin{tabular}{lll}
\hline Ethnic Group & 16.061 & 0.042 \\
Marital Status & 13.294 & 0.348 \\
Education Level & 17.498 & 0.132 \\
\hline
\end{tabular}

Source: Field survey, 2020 and authors' calculation.

It is obvious from the above table that there is a significant association between the initial investment with the demographic variables such as gender and ethnic group. The p-value less than $5 \%$ level of significance justifies it. The p-value more than $5 \%$ level of significance shows that there is no association between initial investment and demographic variables such as age structure, marital status, and education level.

\section{Association between Demographic Variables and Micro-credit}

The association between demographic variables with the micro-credit has been presented in Table 7.

Table 7

Association between Demographic variables and Micro-credit

\begin{tabular}{lll}
\hline Demographic Variables & $\chi^{2}$ & Significance \\
\hline Gender - Household Head & 11.264 & 0.010 \\
Age Structure & 14.918 & 0.093 \\
Ethnic Group & 6.764 & 0.343 \\
Marital Status & 13.766 & 0.131 \\
Education Level & 22.564 & 0.007 \\
\hline
\end{tabular}

Source: Field survey, 2020 and authors' calculation.

The above table reflects that there is an association between the micro-credit with the demographic variables such as gender and the education level. The age structure, ethic group, and marital status are insignificant because p-value of chi-square test is greater than $5 \%$ significance level. It was found that the male household head has taken more amount of loan for micro-enterprises as compared to the female household head. Similarly, the MF clients who have higher level of education (above secondary and secondary) have taken more amount of loan for micro-enterprises as compared to others. Likewise, it was found that the respondents who are in the mid-age (31 to 50 years) have taken more amount of loan for the micro-enterprises as compared to other age structure.

\section{Association between Demographic Variables and Nature of Business}

The association between demographic variables with the nature of business has been presented in Table 8.

Table 8

Association between Demographic Variables and Nature of Business

\begin{tabular}{lll}
\hline Demographic Variables & $\chi^{2}$ & Significance \\
\hline Gender - Household Head & 9.181 & 0.027 \\
Age Structure & 13.091 & 0.159 \\
Ethnic Group & 45.849 & 0.000 \\
Marital Status & 9.966 & 0.353 \\
Education Level & 13.2 & 0.154 \\
\hline
\end{tabular}

Source: Field survey, 2020 and authors' calculation. 
It is obvious from the above table that there is an association between the nature of business with the demographic variables such as gender and ethnic group. The age structure, marital status, and education level are insignificant because p-value of chisquare test is greater than $5 \%$ significance level. It was found that the male household head MF clients are more engaged in the manufacturing and trade related microenterprises while the female household head MF clients are more engaged in agriculture and livestock related micro-enterprises. It was found that dalits are more engaged in service-related micro-enterprises such as tailoring. Likewise, janajati and adhibasi and others (brahmin and chhetri) are more engaged in agriculture and livestock activities.

\section{Correlation Analysis}

The correlation analysis is used to assess the impact of micro-credit on initial investment, employment generation, revenue generation, return on investment, and enterprises expansion. The result of Pearson correlation analysis has been presented in Table 9.

Table 9

Correlation between Dependent and Independent Variables

\begin{tabular}{|c|c|c|c|c|c|c|c|}
\hline & $\begin{array}{l}\text { Micro- } \\
\text { credit } \\
\text { from } \\
\text { MFIs }\end{array}$ & $\begin{array}{l}\text { Initial } \\
\text { Investment }\end{array}$ & $\begin{array}{l}\text { Total } \\
\text { Sales } \\
\text { Revenue }\end{array}$ & $\begin{array}{l}\text { Total } \\
\text { Enterprise } \\
\text { Expenses }\end{array}$ & Total Profit & $\begin{array}{l}\text { Expansion } \\
\text { of Business }\end{array}$ & $\begin{array}{l}\text { Employment } \\
\text { Generation }\end{array}$ \\
\hline \multirow{2}{*}{$\begin{array}{l}\text { Micro credit } \\
\text { from MFIs }\end{array}$} & 1 & $.410^{* *}$ & $.425^{* *}$ & $.368^{* *}$ & $.401^{* *}$ & $.239^{* *}$ & $.434^{* *}$ \\
\hline & & .000 & .000 & .000 & .000 & .002 & .000 \\
\hline \multirow{2}{*}{$\begin{array}{l}\text { Initial } \\
\text { investment }\end{array}$} & $.410^{* *}$ & 1 & $.823^{* *}$ & $.776^{* *}$ & $.591^{* *}$ & $.469^{* *}$ & $.406^{* *}$ \\
\hline & .000 & & .000 & .000 & .000 & .000 & .000 \\
\hline \multirow{2}{*}{$\begin{array}{l}\text { Total Sales } \\
\text { Revenue }\end{array}$} & $.425^{* *}$ & $.823^{* *}$ & 1 & $.913^{* *}$ & $.753^{* *}$ & $.389^{* *}$ & $.502^{* *}$ \\
\hline & .000 & .000 & & .000 & .000 & .000 & .000 \\
\hline \multirow{2}{*}{$\begin{array}{l}\text { Total } \\
\text { Enterprise } \\
\text { Expenses }\end{array}$} & $.368^{* *}$ & $.776^{* *}$ & $.913^{* *}$ & 1 & $.649^{* *}$ & $.340^{* *}$ & $.394^{* *}$ \\
\hline & .000 & .000 & .000 & & .000 & .000 & .000 \\
\hline \multirow[t]{2}{*}{ Total Profit } & $.401^{* *}$ & $.591^{* *}$ & $.753^{* *}$ & $.649^{* *}$ & 1 & $.388^{* *}$ & $.660^{* *}$ \\
\hline & .000 & .000 & .000 & .000 & & .000 & .000 \\
\hline \multirow{2}{*}{$\begin{array}{l}\text { Expansion } \\
\text { of Business }\end{array}$} & $.239^{* *}$ & $.469^{* *}$ & $.389^{* *}$ & $.340^{* *}$ & $.388^{* *}$ & 1 & $.308^{* *}$ \\
\hline & .002 & .000 & .000 & .000 & .000 & & .000 \\
\hline \multirow{2}{*}{$\begin{array}{l}\text { Employment } \\
\text { Generation }\end{array}$} & $.434^{* *}$ & $.406^{* *}$ & $.502^{* *}$ & $.394^{* *}$ & $.660^{* *}$ & $.308^{* *}$ & 1 \\
\hline & .000 & .000 & .000 & .000 & .000 & .000 & \\
\hline
\end{tabular}

Source: Field survey, 2020 and authors' calculation.

**. Correlation is significant at the 0.01 level (2-tailed).

*. Correlation is significant at the 0.05 level (2-tailed).

There is a correlation between the micro-credit and the dependent variables such as initial investment, total sales revenue, total enterprise expenses, total profit, expansion of business, and the employment generation. These variables have a significant positive correlation with the micro-credit from the MFIs. It implies that an increase in the microcredit increases the initial investment in enterprises, sales revenue of enterprises, enterprises expenses, and the profit of the enterprises. Similarly, an increase in the micro-credit also helps in the expansion of business and an increase in the employment generation. 


\section{CONCLUSION AND SUGGESTIONS}

Micro-credit is useful for the small enterprise development. The microfinance institutions provide the micro-credit to the poor, disadvantaged, and unbanked people who have no capacity to pledge mortgage for the loan. There is no requirement of physical collateral for the micro-credit, but the group members may be the collateral. Many studies find that microfinance has successfully enabled the poor people to start their own business generating their own income and often beginning to build up their wealth. It has the capacity to enhance the socio-economic development of the vulnerable and marginalized people, especially women.

The study finds that the majority of the clients are involved in agriculture and livestock and the rest are involved in the micro-business related to service industry (such as tailoring, beauty parlor, hotel or restaurant), trade or business, and small-scale manufacturing sectors. The micro-credit has a positive correlation with the initial investment, revenue generation, employment generation, expansion of business, and profit generation. It has been found that the micro-credit has encouraged clients to engage in micro-business and enterprise development activities. On the basis of above findings, it is necessary to adopt an effective utilization policy of micro-credit that may benefit both microfinance institutions for its sustainability and the clients for their living standard improvement.

\section{Acknowledgement}

We would like to thank Mr. Sadish Tiwari, MBA Graduates, School of Business, Pokhara University for his contribution on data collection.

\section{REFERENCES}

Akhter, J., \& Cheng, K. (2020). Sustainable empowerment initiatives among rural women through microcredit borrowings in bangladesh. Sustainability (Switzerland), 12(6). https://doi.org/10.3390/su12062275

Ang, M. H. (2004). Empowering the poor through micro-credit. International Journal of Entrepreneurship \& Innovation Management, 4(5), 485-494.

Arinaitwe, S. K. (2006). Factors constraining the growth and survival of small-scale businesses: A developing countries analysis. The Journal of American Academy of Business, 8(2), 167-178.

Beck, T., Demirgüç-Kunt, A., \& Maksimovic, V. (2008). Financing patterns around the World: The role of institutions. Journal of Financial Economics, 467-487.

Bhatt, N., Painter, G., \& Tang, S.Y. (1999). Can microcredit work in the United States? Harvard Business Review, 77(6), 26-27.

Copestake, J., Bhalotra, S., \& Johnson, S. (2001). Assessing the impact of microcredit: A Zambian case study. The Journal of Development Studies, 37(4), 81-100.

Dhungana, B. R. (2018). Impact of micro-finance on business creation: A case of Nepal. The Journal of Nepalese Business Studies, 11(1), 23-34.

Dhungana, B. R. (2018). Microfinance intervention and economic transformation in Nepal. The Nepalese Management Review, A Special Issue of International Conference on Emerging Trend and Issues in Management, 44-60, Central Department of Management, Tribhuvan University, Kirtipur, Nepal.

Dhungana, B. R. (2016). Does loan size matter for productive application? Evidence from Nepalese microfinance institutions. The Journal of Business and Hospitality, 1(1), 63-72. 
Dhungana, B. R. (2016). Does micro-finance transform economic status of people? Evidence from western development region of Nepal, The Journal of University Grants Commission, 5(1), 35-48, Bhaktapur, Nepal.

Dhungana, B. R. (2015). Microfinance, micro-enterprises, and employment: A Case of Nepal. The International Journal of Nepalese Academy of Management, 3(1), 78-91.

Green, C. J., Kitkpatrick, S. H., \& Victor,M. (2006). Finance for small enterprise growth and poverty reduction in developing countries. Journal of International Development, 18, 1017-1030.

Hietalahti, J., \& Linden, M. (2006). Socio-economic impacts of microfinance and repayment performance: A case study of the Small Enterprise Foundation, South Africa. Progress in Development Studies, 6(3), 201-210.

Kapoor, V., \& Dhaka, V. (2017). The Impact of microfinance institutions in the development of micro, small and medium enterprises the case of Uttar Pradesh , India ( An Empirical Study ). IOSR Journal of Humanities and Social Science (IOSR, 22(9), 1-8. https://doi.org/10.9790/0837-2209010108

Khalily, M. A. B., \& Khaleque, M. A. (2013). Access to credit and productivity of enterprises in Bangladesh: Is there causality? Institute of Microfinance, Working Paper No. 20.

Khanday, M. I., Shah, B. A., Mir, P. A., \& Rasool, P. A. (2015). Empowerment of women in India-historical perspective. European Academic Research, 2(11), 14494-14505.

Khandker, S. R., Samad, H. A., \& Khan, Z. H. (1998). Income and employment effects of micro-credit programmes: Village-level evidence from Bangladesh. Journal of Development Studies, 35(2), 96-124.

Malhotra, M., Chen, Y., Criscuolo, A., Fan, Q., Hamel, I. I., Savchenko, Y. (2007). Expanding access to finance: Good practices and policies for micro, small and medium enterprises. WBI Learning Resource Series. World Bank, Washington D.C.

Mor, S., Madan, S., Archer, G. R., \& Ashta, A. (2020). Survival of the smallest: A study of micro-enterprises in Haryana, India. Millennial Asia, 11(1), 54-78. doi:10.1177/09763 99619900609

OECD (2006). Financing SMEs and entrepreneurs. OECD Policy Brief. Organisation for Economic Co-operation and Development, Paris.

Rehman, H., Moazzam, A., \& Ansari, N. (2015). Role of microfinance institutions in women empowerment: A case study of Akhuwat, Pakistan. South Asian Studies, 30(1), 107-125.

Salia, P. J., \& Mbwambo, J. S. (2014). Does micro-credit make any difference on borrowers' businesses? Evidences from a survey of women owned microenterprises in Tanzania. International Journal of Social Sciences and Entrepreneurship, 1(9), 431-444.

Schiffer, M., \& Weder, B. (2001). Firm size and the business environment: Worldwide survey results. IFC- Discussion Paper 43. International Finance Corporation, Washington D.C.

Schumpeter, J. A. (1934). The theory of economic development (R. Opie, Trans.). Cambridge MA: Harvard University Press.

Teng, S., Prien, S., Mao, N., \& Ling, B. (2011). Impacts of micro-credit on household economics. International Journal of Environmental and Rural Development, 2(1), 108-114. 
The World Bank (2017). The Global Findex database 2017: Measuring financial inclusion. The World Bank Group.

Wanjiku, E., \& Njiru, A. (2016). Influence of microfinance services on economic empowerment of women in Olkalou constituency, Kenya. International Journal of Research in Business Management, 4(4), 67-78.

Yang, W. (2018). Empirical study on effect of credit constraints on productivity of firms in growth enterprise market of China. Journal of Financial Economics, 6, 173177. 